DOI 10.31558/2519-2949.2021.1.5

УДК 323:352:342.25

ORCID ID: https://orcid.org/0000-0001-5769-7345

Примуш М. В., Донецький національний університет імені Василя Стуса

ORCID ID: https://orcid.org/0000-0001-8376-8979

Ярош Я. Б., Волинський національний університет імені Лесі Украӥнки

\title{
ШЛЯХИ РЕФОРМУВАННЯ ОРГАНІВ МІСЦЕВОГО САМОВРЯДУВАННЯ В УКРАЇНІ У КОНТЕКСТІ ЗАРУБІЖНОГО ДОСВІДУ
}

Статтю присвячено дослідженню основних шляхів щодо реформування органів місцевого самоврядування в україні з огляду на наявний зарубіжний досвід. Беручи до уваги досвід Польщі у процесах впровадження реформ з позичії аналізу їх ефективності, авторами здійснено спробу на практичному та теретичному рівнях з'ясувати, які фактори спричили таку ситуацію, що Украйна та Польща мають діаметрально різні досягнення у вповадженні майже однакових реформ у політичній, економічній та соиіальній сферах з урахуванням того, що чі крайни на початку впровадження реформ знаходилися приблизно на однаковому етапі свого розвитку. Зроблено висновок про те, що оскільки місиеве самоврядування є предметом міжгалузевих досліджень з політології, економіки, сочіології, правознавства та інших наук, це вимагає встановлення методологічних меж комплексного дослідження иього громадянського інституту. 3'ясовано, що, незважаючи на значну кількість теоретико-методологічних підходів дослідження місцевого самоврядування в Україні, вітчизняними фахівиями не створено иілісного уявлення щцодо діяльності самого місиевого самоврядування та його ролі у суспільстві. Доведено, що досі існує суто вітчизняна традиџія досліджувати місиеве самоврядування, виходячи з декларативної його ролі, яка прописана у Законі України «Про місиеве самоврядування в Украӥні», у той самий час вплив політичних та економічних процесів сучасності на місиеве самоврядування й аналіз їх наслідків залишаються недостатньо дослідженими. Визначено, щео в Україні відсутні на рівні держави уявлення щиодо ролі місиевого самоврядування, з одного боку, наголошується на його актуальній $i$ необхідній ролі реалізачії інтересів громади на місиях, а з іншого - питання державного регулювання залишається відкритим. Все ие обумовило появу сучасних досліджень місцевого самоврядування як інноваційної діяльності з моделювання політичних прочесів на місиях.

Ключові слова: місиеве самоврядування, реформа місиевого самоврядування, інвестиційний потениіал, громадське управління.

Процеси реформування економіки, політики та соціальних перетворень взагалі стають центальним явищем і напрямком політичного курсу країни. Але поза увагою дослідників, науковців, політикків залишається явище негативного результату у впровадженні політичних реформ, де політикам-реформаторам бракує досвіду, оскільки ініційовані ними процеси носять або теоретичний характер, або є влучним передвиборчим гаслом. У результаті виникає парадокс, коли країна, знаходячись на певному етапі свого розвитку, у процесі реформування втрачає весь свій реформаторський потенціал та залишається на тому ж самому етапі розвитку, на якому вона була до реформування.

Названа ситуація не $є$ новою в політичній науці й знайшла своє втілення ще в працях представників політичної думки Нового часу, а саме в творчості Джеремі Бентама, Алексіса де Токвіля, Едмунда Берка та інших. Так, Джеремі Бентам вважав, що реформи призводять до появи нових законів, які є злом, тому що або дозволяють анархію, або обмежують свободу, тобто порушують принцип «гармонійного поєднання інтересів суспільства та держави» [1, с. 556-559]. Алексіс де Токвіль вважав, що реформування - це поява нового порядку, який може призвести до втрати принципу «рівності умов», який є гарантією стабільності суспільства [2, с. 150]. Едмунд Берк вважав, що реформи - це містки між теорією, практикою і суспільними викликами у процесі реалізації будь-яких інтересів, задовольнити котрі може лише держава [33, с. 52]. Марксисти, у свою 
чергу, взагалі відкидали будь-який еволюційний шлях розвитку суспільства та вважали, що єдиний шлях розвитку суспільства - це революція та встановлення влади пролетаріату [4, с. 10].

Як бачимо, класики політичної науки та сучасні науковці визнають, що в політичній практиці існує таке явище, як реформування, проте чітко не визначають, чому одні й ті ж самі реформи у державах, які знаходяться у відносно рівних умовах, дають діаметрально протилежні результати.

3 цього приводу, беручи до уваги досвід України та Польщі у процесах впровадження реформ 3 позиції аналізу їх ефективності, нами здійснена спроба на практичному та теретичному рівнях пояснити, які фактори спричили таку ситуацію, що Україна та Польща мають діаметрально різні досягнення у вповадженні майже однакових реформ у політичній, економічній та соціальній сферах з урахуванням того, що ці країни на початку впровадження реформ знаходилися приблизно на однаковому етапі свого розвитку.

Процеси впровадження реформ (політичних, економічних, соціальнних, тощо) в Україні та Польщі здійснювалися одночасно - наприкінці 80-х - на початку 90 -х років XX століття, проте зараз названі держави демонструють діаметрально протилежні результати у позитивних досягненнях реформ. Так, Польщу відносять до країн із найвищими показниками в темпах економічного, політичного та інвестиційного розвитку, де природа досягнень країни не обмежується лише конкретними заходами політичних інституцій чи бюджетними витратами. Україна, як це показують рейтинги впливових світових організацій, знаходиться в списку найменш розвинутих країн світу та Європи і має такий же самий потенціал, як країни Африки [5].

Причини позитивних зрушень в Польщі та багато в чому негативних в Україні, на нашу думку, значно глибші. Тут свою роль відіграє як минулий історичний досвід названих країн, котрий створив умови для формування певних стартових передумов, так і соціокультурний фактор, який дозволив двом суспільствам адаптуватися до процесу впровадження ринкових реформ.

Взагалі, перетворення, які здійснювали уряди Польщі та України протягом посткомуністичного періоду розвитку, розглядаються багатьма дослідниками як «шлях до демократії», а саме, акценти ними робляться тільки на ті реформи, які зорієнтовані на створення політичних інститутів за західними стандартами та зразками демократії, формування демократичних політичних інститутів за зразком та досвідом законодавства країн сталої демократії (політичних партій, громадських організацій, молодіжних рухів, тощо). Однак, на думку К. Оффе, названа ситуація дає нам всі підстави розглядати зміни, що відбуваються в Польщі та в Україні, як складову світового модернізаційного процесу, де панує «свідома настанова держави на здійснення якісних перетворень у суспільстві з урахуванням досвіду передових країн» [6, с. 11]. Тобто названий підхід дозволяє нам одночасно розглядати логіку впровадження реформ та перетворень одразу в декількох кутах зору. Так, за першим, який ми пропонуємо назвати «модернізаційним», пояснення реформ відбувається із двох позицій названого процесу: органічного (наведена країнами так званої сталої західної моделі демократії - США, Канада, Німеччина, Великобританія, Франція), і неорганічного (країни Східної, Південно-Східної Свропи та Латинської Америки) [6, с. 11-12].

Різниця на теоретичному рівні полягає в тому, що країни органічного типу модернізації спочатку ініціювали зміни у духовно-ідеологічній та морально-етичній сферах (Відродження, Реформація, Просвітництво, тощо) і тільки потім трансформували економічну сферу. Потім, з першими позитивними результатами економічних перетворень (нормативно-правовий захист приватної власності), виникали інститути громадянського суспільства (виконували функцію контролю за діями влади), і тільки на самому останньому етапі реформування зміни проходили у політичній системі (інституціоналізація нового порядку). У країнах з неорганічним типом модернізації природа змін пояснюєтся виключно впливом зовнішніх факторів (політичні або військові конфлікти, тощо), які реформують суспільство у зворотньому від органічної модернізації напрямку - спочатку реформується громадянська сфера (переважно штучні політичні інститути), потім економіка (як правило, перерозподіл державної власності між групами впливу), і на фінальному етапі реформується політична сфера (легітимація існуючого порядку групами впливу, які щойно здобули владу).

Україну та Польщу теж можна віднести до країн із неорганічним типом модернізації, оскільки перетворення в них відбуваються у всіх сферах суспільства одночасно, а це, за словами Д. Ептера, свідчить, що «модернізація» в названих суспільствах «є свого роду надією на майбутнє», а реформи надходять від владних інституцій («зверху») та здійснюють «процес трансформації суспільства, який супроводжується реформуванням політичних інститутів, соціальною мобілізацією та розширенням політичної участі, поширенням демократичних цінностей і норм, властивих розвиненим країнам, у країнах менш розвинених» [6, с. 34]. 
Іншими словами, процес переходу до західних стандартів в Україні та Польщі починався зі штучного створення посткомуністичних політичних інститутів на зразок західних, які мали відповідати вимогам та стандартам демократичної держави. Але на практиці спільність між Україною та Польщею на цьому, на нашу думку, завершується. Навіть незважаючи на те, що політична модернізація в посткомуністичних країнах взагалі і в Україні та Польщі зокрема відбувається за майже однаковою схемою: формування демократично налаштованих груп у суспільстві (більшість представників яких мали досвід життя в країнах Заходу), створення всередині них модернізаторської еліти (переважно націоналістичних настроїв) і наступний етап - це прихід названих груп до влади та іiї реалізації (якщо досвід Польщі - це так звана «шокова терапія», то в Україні - це «олігархізація» економічної сфери держави). Також, на нашу думку, слід додати створення нових політичних інститутів та серію ризикованих реформ в економіці (наприклад, стихійна приватизація держпідприємств), де реформатори намагалися відійти від планової моделі економічного розвитку до повністю ринкових відносин, проте при цьому модернізаційний процес повністю визначався владою, а не реальними потребами в ньому суспільства. Тобто реформи в Україні та Польщі ініціювалися та реалізовувалися виключно «зверху», і це є нонсенс, коли влада сама розробляє потреби на реформи та сама їх реалізовує.

На думку польського політолога $\mathcal{C}$. Вятра, «реформа «зверху»- це реформування політичних інститутів для представників еліти задля реалізації ії інтересів [7, с. 83], що означає фактичну відсутність в країні громадянського суспільства». Як наслідок, на нашу думку, така демократична категорія, як контроль за владою з боку суспільства або відсутня, або не працює 3 причини відсутності певних умов (відповідного законодавства), що викликає не тільки зменшення темпів реформ, а невідомий шлях їх подальшої реалізації. У Польщі, на відміну від України, така ситуація не була настільки насичена авторитарним історичним досвідом, оскільки в польській системі організації влади збереглися дорадянські політичні інститути: по-перше, це багатопартійна система (зауважимо, що вона мала формальний характер, проте факт ії існування не заперечується), автономне селянство (у Польщі, як відомо, радянська політика колективізації зазнала поразки), певна незалежність вищих навчальних закладів та політично активне академічне середовище. Названі фактори, на думку Х. Лінця та А. Степана, свідчать про те, що «Польща була найслабшою ланкою в міжнародному ланцюгу командно-адміністративних систем і ніколи не проводила етап крайнього тоталітаризму» [8, с. 257]. Тобто другий кут зору на проблему особливостей впровадження політичних реформ в Україні та Польщі дозволяє нам визначити, що на ментальному рівні населення Польщі було більш адаптованим до реформ, оскільки вони асоціювалися 3 поверненням до зруйнованої радянською владою демократії, і взагалі, польському суспільству вдалося зберегти для більш вдалого реформування відповідні політичні інститути, а також Польщі вдалося головне не до кінця реалізувати всередині країни радянські реформи.

Отже, третій кут зору на проблему особливостей вповадження реформ в Україні та Польщі ми пропонуємо назвати «інституційним», оскільки він пояснює, що негативних проявів системи «реформування зверху» не вдалося уникнути ані Україні, ані Польщі. Навіть незважаючи, як це ми з'ясували, на факт ментальної підготовки польського суспільства до необхідних реформ. Наприклад, процес прийняття Конституції України в 1996 р. та Конституції Польщі в 1997 р., на нашу думку, породив дилему: приймати закони «пакетами за максимально короткий час» чи забезпечити їх високу ефективність та якість. Прикладом цього слугує той факт, що українська Конституція приймалася «за одну ніч», у той самий час, коли Польщі для цього знадобилося набагато більше часу. Названий факт ще раз доводить нашу думку з приводу того, що транзит демократії у країни, котрі не мають історичного та ментального досвіду втілення в життя європейських стандартів політики, призводить до гібридизації політичної системи $\mathrm{i}$, як наслідок, відхилення громадянського суспільства від контролю за владою, тобто унеможливлює весь теоретичний та практичний потенціал реформ, як це відбувається в Україні.

Польщі, на нашу думку, вдалося уникнути такої ситуації вдалою судовою реформою та реформою місцевого самоврядування, що в сумі з іншими реформами поліпшили інвестиційний потенціал країни. Незважаючи на те, що судова система Польщі більш диференційована, порівняно з Україною, проте вона має більшу довіру у суспільстві. Так, згідно з польською Конституцією: «Державний трибунал як спеціалізований орган конституційної юстиції, який вирішує справи про конституційну відповідальність посадових осіб, виносить рішення про відповідальність (адміністративну, кримінальну, тощо) осіб, які займають найвищі державні посади, за порушення Конституції та інших законів держави» [9, с. 187]. На нашу думку, цей орган було створено не для 
того, щоб як за українською практикою, «давати показники», а щоб викликати довіру населення до судової системи, що призвело до того, що польські громадяни стали активно втручатися у справи контролю над владою, про що також свідчить постійне зростання кількості судових позовів.

Другим, на нашу думку, важливим аспектом польського досвіду «позитивного реформування» стало реформування місцевого самоврядування шляхом впровадження ідеї децентралізації, яка покликала «забезпечити поєднання в собі» інституційного і особистісного початку у процесі суспільно-політичного розвитку» [10, с. 181].

Саме місцеве самоврядування, на думку польських реформаторів, здатне поєднати i гармонізувати інтереси кожної окремої особи і суспільства. Європейська Хатрія про місцеве самоврядування під цим інститутом розуміє «право i реальну здатність органів місцевого самоврядування регламентувати значну частину місцевих справ і управляти ними, діючи в межах закону та в інтересах місцевого населення» [10].

На практиці реформування самоврядування і в Україні, і в Польщі, було відроджено за такими принципами: «самостійності і незалежності» місцевих виборчих органів у межах своїх повноважень вирішувати питання місцевого значення; економічної і фінансової самостійності території; самофінансування і самозабезпечення; оптимальної децентралізації» [11, с. 181]. Проте в Україні, згідно з законом, «місцеве самоврядування здійснюється територіальною громадою безпосередньо або через органи місцевого самоврядування - Ради, що обираються громадянами, які проживають на території відповідної адміністративно-територіальної одиниці», у той самий час, як в Польщі місцеве самоврядування «здійснюється через гміну - основну одиницю територіального самоврядування, яка має колегіально вирішувати питання місцевого значення» [12, с. 183], отже, на нашу думку, названі процеси свідчать про невизначеність соціально-економічної спрямованості та орієнтирів переходу від однієї соціально-політичної моделі до іншої, що тільки посилює негативний вплив на становлення органів місцевого самоврядування в політичній системі. Спробуємо це довести на прикладі порівняння іноземних інвестицій у Польщу та Україну за 2004, 2011 та 2013 роки (табл. 1, табл. 2). Названі терміни порівняння обрано не випадково, оскільки Польща, яка орієнтувала, на нашу думку, свої реформи задля вступу до СС (2004) та отримання пільгових кредитів МВФ, досягла своєї мети; у свою чергу, 2011 рік як період, який максимально показує привабливість країни в очах інвесторів, особливо коли вона вживає певних заходів, у нашому випадку - Свро-2012.

Таблиия 1

\section{Прямі іноземні інвестиції в Польщі та в Україні за 2004 рік (у млрд. доларів США) ${ }^{[12]}$}

\begin{tabular}{|c|c|}
\hline \multicolumn{1}{|c|}{ Краӥна } & Сума інвестицій \\
\hline Польща & 56,7 \\
\hline Україна & 42,2 \\
\hline
\end{tabular}

Таким чином, підсумовуючи наведені факти, можна зробити висновок, що Польща на момент вступу до ЄС отримала на 14,5 млрд. доларів інвестицій більше, ніж Україна за ці роки незалежності. Представлене ще раз ілюструє факт того, що польська влада у процесі реформування закладала мету побудування інвестиційно привабливої країни. Але це не означає, що Польща вже виконала своє завдання-«максимум» в інвестиційній привабливості країни. Як ми вже розглядали, Польща має ще багато невирішених проблем, але вона, знаходячись навіть у більш складному економічному становищі, змогла вийти на якісні показники протягом досить короткого часового відрізку.

Таблиия 2

Прямі іноземні інвестиції в Польщі та в Украӥні
за 2011-2013 роки (у млрд. доларів США)

\begin{tabular}{|c|c|}
\hline \multicolumn{1}{|c|}{ Краӥна } & Сума інвестицій \\
\hline Польща & 68,9 \\
\hline Україна & 49,3 \\
\hline
\end{tabular}


Наведені нами дані показують не тільки факт того, що між Польщею та Україною розрив у інвестиційній привабливості країни становить вже 19,6 млрд. доларів США, а також те, що темпи збільшення інвестиційної привабливості України вкрай низькі. Якщо Польща за 7 років збільшила інвестиційну привабливість на 12,2 млрд. доларів США, то Україна, незважаючи на активну політику впровадження нових європейських реформ, проєкти Євро-2012, змогла за той же самий час збільшити свою привабливість в очах інвесторів тільки на 7,1 млрд. доларів США, тобто майже на половину менше, ніж республіка Польща.

На нашу думку, така ситуація ще раз доводить нашу тезу про те, що вдала судова система, котрій довіряє більшість населення, та ефективна система місцевого самоврядування, котра включає участь у політичних процесах більшості громадян, дозволяє останнім тільки вигравати, питання тут не стільки у збільшенні інвестицій, скільки увпевненості населення в успішності обраного політичного курсу, і саме ця впевненість і об'єднує націю та довзоляє реформаторам, з одного боку, пом'якшити негативні явища реформ (у Польщі, наприклад, це була вже згадувана нами «шокова терапія»), а з іншого боку, створити умови для активного залучення громадян у процес реалізації реформ (в Україні, навпаки, влада спочатку обговорює реформи, а потім самостійно їх реалізує). Ключовим фактором, однак, має слугувати довіра та віра населення у правильність політичного курсу. Через це, на нашу думку, слід обмежити українським реформаторам копіювання польського досвіду, оскільки, як ми це вже зазначили, на ментальному рівні польське суспільство більш підготовлене до реформ, ніж українське.

Також слід окремо зазначити, що головною умовою успішності процесів реформування має стати створення ефективної багатопартійної системи, оскільки в сучасних політичних умовах саме політичні партії є посередниками між державою і громадянином, виконуючи, за Е. Пуфлером, функції «механізму самоорганізації суспільної системи, а політична боротьба між партіями, що конкурують, стає рушієм розвитку, сприяючи формуванню демократичним шляхом загальнонаціональних інтересів та цілей», які дозволяють підняти рівень відповідальності за стан справ речей у державі до персоніфікованого рівня [14, с. 36]. Наприклад, Конституції Польщі та України із цього приводу закріплюють відповідні політичні умови, які необхідні для розвитку багатопартійності на основі одного $з$ ключових принципів демократії, а саме добровільності і рівності громадян з метою впливу демократичними методами на формування та реалізацію державної політики [15] та влади [16].

Таким чином, аналізуючи практику впровадження реформ в Україні крізь призму досвіду республіки Польща, ми зробили такі висновки. Існуюча в Україні модель впровадження реформ $\epsilon$ вертикально зорієнтованою, тобто гібридною, проте якщо на місцевому рівні організації влади вона повністю копіює зразок влади з минулої радянської практики (що ще раз виступає одним із факторів незадовільного стану української економіки, оскільки більшість промислово розвинутих регіонів $€$ дотаційними), то на загальнонаціональному рівні українська влада шляхом побудови політичних інститутів громадянського суспільства дає всі підстави стверджувати, що Україна упроцесі впровадження реформ зіткнулася з дилемою: чи створювати в державі ефективні громадянські інститути та делегувати їм відповідні повноваження, чи далі розвивати рядянський досвід побудови жорсткої ієрархії влади, який призвів до того, що реформування мало не певні позитивні результати, а їхню імітацію. Навіть більш того, аналізуючи український досвід можна вести мову про існування подвійного стандарту у діяльності українських реформаторів: по-перше, це створення декларативної моделі влади та тієї, яка успішно функціонує в політичній реальності, тобто створює значну розбіжність між Конституцією як офіційним нормативно-правовим документом та фактичним станом щодо реалізації ії положень на практиці. У результаті такої ситуації в Україні програють всі, оскільки залежніть судової влади від певної політичної групи тиску та виконання нею репресивних функцій, незрілість громадянських інститутів, які нездатні контролювати діяльність влади, й наостанок застаріла модель місцевого самоврядування, котра не дозволяє регіонам отримати власні політикоправові ресурси, вільно керувати політикою та економікою власного регіону, призводять до повільних реформ та ще більшої незрілості політичних інститутів і суспільства в цілому.

Отже, проблеми незрілості України у реалізації реформ спричинені не стільки ії комуністичним етапом розвитку (де головне - це подобатися всім), а також тим, що Україна сліпо копіює всі процеси модернізації, серед яких можна назвати «вестернізацію», часткову або імітаційну модель модернізації, що не тільки не поліпшує стан справ в Україні, а навпаки - залишає нашу державу на тих самих позиціях, котрі вона мала після проголошення незалежності.

Отже, за відсутності в Україні ринкових механізмів стабільного економічного зростання, наявними розбіжностями між конституційною та реально існуючою системою політичних відносин 
не виключена загроза того, що реформування набуде (якщо вже не набуло) виключно штучного характеру, а роль демократичних інститутів при цьому буде зведена лише до їх наявної функції. Для запобігання цьому не варто механічно копіювати досвід Польщі як країни, яка вдало вирішує завдання втілення реформ за принципом «зверху» (зазначимо, що й повне ігнорування цього досвіду також $є$ помилкою), а необхідно виробити власний, більш прийнятний шлях, який можна назвати як поліпшення інвестиційного клімату в Україні з метою побудови конкурентоспроможної держави. Але для цього потрібні не стільки воля держави, скільки розуміння у населення того факту, що українським реформам бракує досвіду та, як результат, процес впровадження реформ є досить тривалим і не відразу приносить очікуваний результат.

Складність такого розуміння полягає у тому, що на теоретичному рівні місцеве самоврядування являє собою громадянсько-політичний інститут представницької демократії зі специфічною функцією реалізації громадянами свого права вільно вирішувати місцеві питання за державними правовими гарантіями й за бюджетні кошти. 3 одного боку, це забезпечує репрезентацію інтересів громадян на місцях, а з іншого - місцеве самоврядування, виступаючи посередником у владнополітичних відносинах між громадянином та центральною владою, займає власне місце у політичній системі будь-якої країни. Названа ситуація призвела до появи другого рівня, який нами окреслено як практичний. На цьому рівні місцеве самоврядування аналізується 3 позицій полідисциплінарного підходу з урахуванням сцецифіки предметів політичних, історичних, юридичних, економічних і навіть технічних наук, і головне - враховується логіка нормативно-правової діяльності органів місцевого самоврядування. Окреслена ситуація зумовила центральну проблему дослідження, яка полягає у вирішенні методологічної колізії. Сутність полягає у тому, що місцеве самоврядування необхідно досліджувати одночасно як об'єкт владно-політичних стосунків громадянсько суспільства і державної влади та як суб'єкт економіко-правого регулювання. Саме це продиктовано логікою полідисциплінарного підходу, що вимагає від дослідника відійти від побудови універсального теоретико-методологічного підходу дослідження місцевого самоврядування шляхом впровадження комплексних міжгалузевих досліджень.

Мова йде про врахування специфічних рис місцевого самоврядування як політичного, громадянсько-політичного інституту, суб'єкта державного та недержавного господарювання й політико-правової організації соціально-владних відносин, де місцеве самоврядування виступає як інститут громадсько-владних та як суб'єкт економіко-правих аспектів врегулювання владнополітичних взаємовідносин на місцях. Тому виникає гостра потреба у побудуванні комплексної методології досідження місцевого самоврядування, що здійснюється шляхом аналізу існуючих теоретико-методологічних підходів у роботах вітчизняних фахівців з місцевого самоврядування в Україні. Як показує аналіз джерельної бази дослідження, проблематика місцевого самоврядування в Україні висвітлена достатньо широко. Створено теоретико-методологічні підходи щодо історичної (О. Івановська, Н. Камінська, С. Могильний) та юридичної (Л. Беззубко, В. Бороденюк, І. Дробуш) практик мсцевого самоврядування в Україні у контексті досвіду країн сталої демократії (I. Алексєєнко, Б. Свірський); аргументовано інноваційні теорії шляхів реформування й вдосконалення місцевого самоврядування (М. Примуш, Ю. Коваль) та аналізу дефомацій посттоталітарних владних відносин (Ю. Харбих). Окремо слід навести дослідження І. Дробуша 3 приводу функціонального навантаження органів місцевого самоврядування та дослідження Ю. Бальція щодо стратегічного аналізу проблем сучасного стану місцевого самоврядування в Україні у констексті євроінтеграційних процесів міської та селищної влади. До новітніх досліджень місцевого самоврядування належать роботи В. Горбика з приводу моделювання політичних процесів і формату державної регуляторної політики на місцях та економіко-інноваційний підхід Д. Тарасенка, де місцеве самоврядування виступає синергетичним елементом саморозвитку економічної ефективності та політичної стабільності всієї держави.

Таке різноманіття підходів свідчить про те, що місцве самоврядування являє собою таку систему, яка одночасно забезпечує стабільність усієї політичної системи держави, відповідає на соціально-політичні виклики громадян, формує господарську та економічну діяльність i виступає елементом впровадження та адаптації новацій. 3 цього приводу відома вітчизняна дослідниця I. Алексєєнко зазначає, що місцеве самоврядування також виступає своєрідним каталізатором владно-політичних відносин з протидії двох крайнощів - не дозволяє громадянському суспільству необмежено керувати місцевою владою, що може викликати прямі загрози національній безпеці (сепаратизм), й обмежує роль центрального уряду щодо втручання у вирішення місцевих питань. Такий фунціональний дуалізм дещо спрощує конструювання 
комплексного підходу дослідження місцевого самоврядування. Розведення по різних кутах громадського управління й державного втручання означає, що місцеве самоврядування $\epsilon$ легалізованим елементом політичної системи, який реалізує з одного боку делеговані центральним урядом повноваження, а з іншого - воно наділено реальною спроможністю впливати на громадські процеси на місцях. Саме у визначенні названих меж i проходить дослідження місцевого самоврядування в Україні, і це, на наш погляд, є цілком справедливим з методологічних позицій, але неефективним у плані реальної практики місцевого самоврядування. На користь нашої думки також висловлюється В. Гнилорибов, який зазначає, що адміністративний рівень місцевого самоврядування в Україні складено на двох системах. До першої, місцевої або сільської, відноситься існуючий декларативний рівень місцевого самоврядування із залученням громадян до влади і можливостями рішення власних проблем на місцях. Друга система, навпаки, наведена регіональною чи обласною системою вже державної влади, і місцевого самоврядування у цій системі немає, бо не відбувається прямого залучення громадян до управління.

Мова йде про те, що перший (громадське управління на місцях) та другий (державне втручання у місцеве самоврядування) випадки $є$ теоретичними і будуються навколо загальної ідеї місцевого самоврядування щодо виконання ним делегованих центральним урядом повноважень у правових межах гарантій такої діяльності. В Україні сформований вектор засвідчує, що за Конституцією України єдиним джерелом і носієм влади є український народ, який здійснює владу безпосередньо через органи державної влади та органи місцевого самоврядування (ст. 5) [17]. При цьому і Закон України «Про місцеве самоврядування (ст. 2) [18], і Конституція України (ст. 140) [17] гарантують місцевому самоврядуванню право самостійно вирішувати питання місцевого значення в межах Конституції і законів України [19, с. 265]. Тобто, як зауважує В. Борденюк, на декларативному рівні в Україні створено всі умови для існування місцевого самоврядування, і тому вектор досліджень потрібно змінити від вивчення загальних моделей місцевого самоврядування (континентальна, федеральна, змішана) до побудови систем впровадження правових реформ, господарського удосконалення та інновацій на місцевому рівні. Проте, як показує практика, подібні дослідження лише наголошують на певних змінах у сфері місцевого самоврядування, але рішень не пропонують. На нашу думку, метою переважної більшості досліджень з місцевого самоврядування в Україні $\epsilon$ розробка методологічних засобів удосконалення місцевого самоврядування як ефективної системи місцевого економіко-політичного менеджменту задля створення привабливого інвестиційного клімату, впровадження основ вільної економічної та політичної конкуренції у певному регіоні. Кінцевою метою наведених досліджень $є$ побудова регіональної бюджетної моделі, заснованої на принципах ефективного використання місцевим самоврядуванням доходів з місцевих податків транфертів з державного бюджету, та дослідження впливу такої моделі на соціально-політичні процеси в умовах України. На наш погляд, недоліком такого підходу є перебільшення ролі місцевої еліти щодо формування ефективної регіональної політики. Окремо слід відзначити, що фінансова автономія регіонів має зворотній ефект у вигляді появи місцевих монополій певних регіональних груп, що актуалізує питання економічної підтримки питання сепаратизму.

На практичному рівні зазначеного питання ми отримуємо дві діаметрально протилежні позиції на проблему дієздатності місцевого самоврядування. Перша позиція наведена переважно державними службовцями, безпосередньо задіяними у місцевому самоврядуванні (сільські голови, мери міст, керівники районів та областей), і має внутрішню дуальність поглядів з позиції реалізації місцевим самоврядуванням законного права на свою дієздатність. Підсумовуючи позиції державних службовців з інтерв'ю, звітів, мемуарів та підготовлених матеріалів ми знаходимо таку логіку. Місцеве самоврядування $є$ актуальним та необхідним явищем, що забезпечує економічний розвиток та політичну стабільність всієї країни. При цьому, на думку Т. Дики, держава не повинна сліпо забезпечувати бюджетними гарантіями місцеве самоврядування, а, скоріше, створює реальні гарантії фінансової незалежності місцевого самоврядування, що дозволять йому отримати нові імпульси свого розвитку й побудови ефективної місцевої економіки на місцях. Названа ситуація гостро підіймає питання підзвітності такої «свободи» місцевого самоврядування, відповідь на яке вже не демонструє повної згоди між ним та державними інституціями. Центральна влада запевняє, що контроль має здійснювати держава, а не місцева громада. Отже, головним недоліком цього підходу виступає питання реалізації гарантованого державою права місцевим громадам на певну автономність, яке не знаходить єдиної позиції у своїй реалізації. На нашу думку, слабке розуміння державними службовцями реального сенсу існування місцевого самоврядування не як найменшого рівня влади, а як інституту громадянського суспільства. Невирішеним через названу дуальність залишаються 
питання фінансування місцевого самоврядування, недостатня компетентність посадовців та непрозорість у процесах прийняття рішень на місцях (наприклад, виділення маєтків для забудівлі без моніторингу громадської думки населення, що мешкає на цій території). На наше переконання, слід також навести думку відомого українського дослідника С. Телешуна, який із цього приводу засвідчує, що українська влада всіх рівнів має одну загальну рису щодо аргументації супутніх проблем місцевого самоврядування, у той самий час, коли реальні лежать набагато глибше, ніж здається посадовцям. Аналізуючи владно-політичні процеси всіх рівнів, він вживає таке поняття, як «нефункціональна демократія» в Україні й наводить такі аргументи:

- будь-які політичні процеси є штучно заполітизованими;

- інститути громадянського суспільства нерозвинені й перебувають ще устадії свого оформлення;

- нерозвинена соціальна структура суспільства та відсутність механізмів реалізації інтересів основних соціальних груп;

- корумпованість державного апарату та його залежність від політичних і фінансових груп.

На нашу думку, з наведеного виходить, що місцеве самоврядування діє у політико-економічній невизначеності. Відчуваючи реальне суспільне замовлення на дієздатну місцеву владу, остання перебуває під впливом трьох системних криз всієї державної вертикалі. По-перше, відчувається вплив політизації громадського життя, і тому місцеве самоврядування формується як нижній рівень державної влади. Мова йде про те, що органи місцевого самоврядування транслюють на місця політичні конфлікти влади й опозиції. Нещодавня ситуація із Законом України «Про засади державної мовної політики» це наочно демонструє. На перший погляд здається, що питання мови національних меншин було вирішено назавжди, оскільки ними було отримано державні гарантії на розвиток «рідної» мови національних меншин. Натомість, як показала практика реального життя, названий закон викликав всебічне обурення не тільки представників титульної нації, але й представників національних меншин, бо реальних умов для реалізації державних гарантій щодо рішення «мовного питання〉 створено не було. По-друге, громадянське суспільство, перебуваючи у стадії свого оформлення, поки що не зацівлено у створенні громадянських інститутів через відсутність реальних правових механізмів впливу на процеси прийняття політичних рішень. I нарешті, по-третє, системна криза торкається питання загальної слабкості політичних інститутів усіх рівнів влади в Україні. Причиною слабкості, на наш погляд, є залежність офіційної влади від впливу інтересів фінансовопромислових груп, котрі зацікавлені реалізувати приватний інтерес не на регіональному рівні, а вже на національному, і тим самим отримувати набагато більші дивіденди.

Наведена ситуація стану досліджень місцевого самоврядування в Україні підіймає актуальність інноваційних досліджень (Д. Тарасенко) та теорії моделювання політичних процесів (В. Горбик). Сутність полягає у орієнтації місцевого самоврядування в Україні на реалізацію економічної діяльності під політичними гарантіями державної влади вільно вирішувати власні питання. Вирішити цю проблему намагається В. Горбик. Акцентучи увагу на специфіці економічних та соціальних процесів кожного регіону, він зазначає, що вони мають різний ресурсний потенціал і тому необхідно встановити розмежування процесів на наочність та аналіз. До першого відходить інформаційне забезпечення (правова база) використання місцевим самоврядуванням власного ресурсного потенціалу. До другого рівня відносяться адміністративні процеси з проектування, розробки та моніторингу ресурсного потенціалу (економічного, інтелектуального, геополітичного) певного регіону [20, с. 22]. На наше переконання, така модель має сенс, незважаючи на ії теоретичність, оскільки тут не відбувається втручання держави у процеси забезпечення й використання ресурсного потенціалу певного регіону. Навпаки, держава реалізовує встановлене нормативно-правовою базою право місцевого самоврядування вільно вирішувати власні питання й окреслює разом із місцевою громадою вектор моніторингу та обмеженого контролю щодо його діяльності. Головне досягнення підходу В. Горбика - це закріплення за місцевим самоврядуванням права вільно проектувати та реалізовувати свій ресурсний потенціал для вирішення власних проблем. Але недоліком тут виступає ігнорування фактора політичної корупції та її впливу на політичні процеси в Україні (мається на увазі державні й регіональні рівні влади). На думку Г. Кохана, корупція в Україні стала структурним елементом політичної системи нашої держави, де вона оформилася вже як певний вид діяльності, різновид обміну між об'єктами та суб'єктами владних взаємовідносин і взагалі стала певною традицією. За такої ситуації моделювання політичних процесів без урахування корупції як активного фактора впливу робить дослідження нечітким й унеможливлює його реалізацію на практиці, тому у самостійний підхід названі дослідження ще не оформилися. Також у дослідженнях, де місцеве 
самоврядування розглядається не як інститут, а як модель забезпечення комунікативних складових процесів політико-економічного обміну певних регіонів, зростає необхідність уточнення як методології, так і предмету аналізу.

Таким чином, підсумовуючи результати дослідження, ми дійшли таких висновків. По-перше, місцеве самоврядування є предметом міжгалузевих досліджень з політології, економіки, соціології, правознавства та інших наук, що вимагає від науковця встановлення методологічних меж комплексного дослідження цього громадянського інституту. А це, усвою чергу, залишає недослідженим цілу низку аспектів місцевого самоврядування, серед яких є господарсько-економічна діяльність та іiі вплив на політико-правове оформлення владно-політичних взаємовідносин влади 3 місцевими громадами. По-друге, незважаючи на значну кількість теоретико-методологічних підходів дослідження місцевого самоврядування в Україні, вітчизняними фахівцями не створено цілісного уявлення щодо діяльності самого місцевого самоврядування та його ролі у суспільстві. Натомість існує суто вітчизняна традиція досліджувати місцеве самоврядування, виходячи 3 декларативної його ролі, яка прописана у Законі України «Про місцеве самоврядування в Україні», у той самий час вплив політичних та економічних процесів сучасності на місцеве самоврядування й аналіз їх наслідків залишається недостатньо дослідженим. I нарешті, по-третє, в Україні відсутні на рівні держави уявлення щодо ролі місцевого самоврядування, з одного боку, наголошується на його актуальній і необхідній ролі реалізації інтересів громади на місцях, а з іншого - питання державного регулювання залишається відкритим. Все це обумовило появу сучасних досліджень місцевого самоврядування як інноваційної діяльності з моделювання політичних процесів на місцях, проте через брак досвіду названий аспект, залишаючись актуальним, ще проходить своє теоретикометодологічне оформлення.

\section{Бібліографічний список:}

1. Антология политической мысли: в 5 т. Зарубежная политическая мысль: истоки и эволюция. М.: 1997. T. $1831 \mathrm{c}$.

2. Токвіль де Алексіс. Про демократію в Америці / Пер. $з$ фр. Григорія Філіпчука та Михайла

Москаленка; Передмова Андре Жардена. К.: Видавничий дім «Всесвіт», 1999. 590 с.

3. Берк Э. Размышления о революции во Франции и заседаниях некоторых обществ в Лондоне, относящихся к этому событию. М., 1993. 144 с.

4. Социал-демократия сегодня. М., 2002. С. 8-16.

5. Рейтинг інвестиційної привабливості регіонів України. URL : http://www.expert.ua/articles/25/0/1412/.

6. Оффе К. Культурные аспекты консолидации: заметки об особенностях посткоммунистической трансформации Конституционное право: Восточноевропейское обозрение. 1998. №1. С. 9-13.

7. Політичний календар. 1999. №8. С. 34-40.

8. Вятр Е. Трансформация тоталитарных и авторитарных режимов в современной демократии / E. Вятр Лекиии по политологии. Таллинн, $1991.260 \mathrm{c}$.

9. Linz L. Problems of Democratic Transformation and Consolidation / L. Linz A. Stepan. Southern Europe, South America, Post-Communist Europe. 1996. P. 255-292.

10. Горбатенко В. П. Стратегія модернізації суспільства: Україна і світ на зламі тисячоліть. К., 1999. $240 \mathrm{c}$.

11. Європейська Хартія місцевого самоврядування. Страсбург, 15 жовтня 1985 року

URL : http://zakon4.rada.gov.ua/laws/show/994_036.

12. Горбатенко В. П. Стратегія модернізації суспільства: Україна і світ на зламі тисячоліть

/ В. П. Горбатенко. - К., 1999. - 240 с.

13. Гальчинський А. Іноземні інвестиції: проблеми та перспективи. Дзеркало тижня. 2005. №36.

URL: http://dt.ua/ECONOMICS/inozemni_investitsiyi_problemi_ta_perspectivi-44588.html.

14. Инвестиции в Евро-2012 на территории Польши достигли 20 млрд. евро. URL:

http://www.rbc.ua/rus/top/show/investitsii-v-evro-2012-na-territorii-polshi-dostigli-20-mlrd-01072012184300/

15. Пуфлер Е. Партійна система незалежної України: особливості формування, тенденції подальшої трансформації. Нова політика. 1997. №1. С. 308.

16. Конституция Республики Польша от 2 апреля 1997 г. Дневник Законов от 16 июля 1997 г. \pm 78 , поз.

483. URL: http://www.sejm.gov.pl/prawo/konst/rosyjski/kon1.htm.

17. Конституція України. Відомості Верховної Ради Украӥни (ВВР). 1996. №30. Ст. 141.

URL: http://zakon2.rada.gov.ua/laws/show/254\%D0\%BA/96-\%D0\%B2\%D1\%80.

18. Закон України «Про місцеве самоврядування в Україні» URL: http://zakon2.rada.gov.ua/laws/show/ 280/97-\%D0\%B2\%D1\%80.

19. Збірник законів пр місцеве самоврядування. Луганськ : Б. в., 2003 - С. 265. C. 6-33.

20. Инглхарт Р. Постмодерн: меняющиеся ценности и изменяющиеся общества. Полис. 1997. №4. 


\section{References:}

1. Antolohyia polytycheskoi misly: v 5 t. Zarubezhnaia polytycheskaia misl: ystoky y evoliutsyia. M.: 1997. T. $1831 \mathrm{~s}$.

2. Tokvil de Aleksis. Pro demokratiiu v Amerytsi / Per. z fr. Hryhoriia Filipchuka ta Mykhaila Moskalenka; Peredmova Andre Zhardena. K.: Vydavnychyi dim «Vsesvit», 1999. $590 \mathrm{~s}$.

3. Berk E. Razmishlenyia o revoliutsyy vo Frantsyy y zasedanyiakh nekotorikh obshchestv v Londone, otnosiashchykhsia k etomu sobityiu. M., 1993. $144 \mathrm{~s}$.

4. Sotsyal-demokratyia sehodnia. M., 2002. S. 8-16.

5. Reitynh investytsiinoi pryvablyvosti rehioniv Ukrainy. URL : http://www.expert.ua/articles/25/0/1412/.

6. Offe K. Kulturnie aspekti konsolydatsyy: zametky ob osobennostiakh postkommunystycheskoi transformatsyy. Konstytutsyonnoe pravo: Vostochnoevropeiskoe obozrenye. 1998. №1. S. 9-13.

7. Politychnyi kalendar. 1999. №8. S. 34-40.

8. Viatr E. Transformatsyia totalytarnikh y avtorytarnikh rezhymov v sovremennoi demokratyy / E. Viatr Lektsyy po polytolohyy. Tallynn, 1991.260 s.

9. Linz L. Problems of Democratic Transformation and Consolidation / L. Linz A. Stepan. Southern Europe, South America, Post-Communist Europe. 1996. P. 255-292.

10. Horbatenko V. P. Stratehiia modernizatsii suspilstva: Ukraina i svit na zlami tysiacholit. K., 1999. $240 \mathrm{~s}$.

11. Yevropeiska Khartiia mistsevoho samovriaduvannia. Strasburh, 15 zhovtnia 1985 roku.

URL: http://zakon4.rada.gov.ua/laws/show/994_036.

12. Horbatenko V. P. Stratehiia modernizatsii suspilstva: Ukraina i svit na zlami tysiacholit / V. P. Horbatenko. K., 1999. $-240 \mathrm{~s}$.

13. Halchynskyi A. Inozemni investytsii: problemy ta perspektyvy. Dzerkalo tyzhnia. 2005 . №36.

URL: http://dt.ua/ECONOMICS/inozemni_investitsiyi_problemi_ta_perspectivi-44588.html.

14. Ynvestytsyy v Evro-2012 na terrytoryy Polshy dostyhly 20 mlrd. evro. URL:

http://www.rbc.ua/rus/top/show/investitsii-v-evro-2012-na-territorii-polshi-dostigli-20-mlrd-01072012184300/

15. Pufler E. Partiina systema nezalezhnoi Ukrainy: osoblyvosti formuvannia, tendentsii podalshoi transformatsii. Nova polityka. 1997. №1. C. 308.

16. Konstytutsyia Respublyky Polsha ot 2 aprelia 1997 h. Dnevnyk Zakonov ot 16 yiulia 1997 h. \pm 78 , poz. 483. URL: http://www.sejm.gov.pl/prawo/konst/rosyjski/kon1.htm.

17. Konstytutsiia Ukrainy. Vidomosti Verkhovnoi Rady Ukrainy (VVR). 1996. №30. St. 141.

URL: http://zakon2.rada.gov.ua/laws/show/254\%D0\%BA/96-\%D0\%B2\%D1\%80.

18. Zakon Ukrainy «Pro mistseve samovriaduvannia v Ukraini». URL: http://zakon2.rada.gov.ua/laws/show/ 280/97-\%D0\%B2\%D1\%80.

19. Zbirnyk zakoniv pr mistseve samovriaduvannia. Luhansk : B. v., 2003 - S. 265.

20. Inglehart R. Postmodern: meniaiushchyesia tsennosty y yzmeniaiushchyesia obshchestva. Polys. 1997. №4. C. 6-33.

\section{Prymush M. V., Yarosh Ya. B. Measures for Reforming Local Government Bodies in Ukraine in the Context of Foreign Experience}

The article is devoted to the study of the main ways to reform local governments in Ukraine in view of the available foreign experience. Taking into account the experience of Poland in the implementation of reforms from the standpoint of analysis of their effectiveness, the authors tried to find out on a practical and theoretical level what factors caused the situation that Ukraine and Poland have diametrically different achievements in implementing almost identical reforms in political, economic and social spheres, given that these countries were at about the same stage of development at the beginning of the reforms. It is concluded that since local self-government is the subject of intersectoral research in political science, economics, sociology, law and other sciences, it requires the establishment of methodological boundaries of a comprehensive study of this civic institution. It was found that, despite the significant number of theoretical and methodological approaches to the study of local self-government in Ukraine, domestic experts have not created a holistic view of the activities of local self-government and its role in society. It is proved that there is still a purely national tradition of studying local self-government, based on its declarative role, which is enshrined in the Law of Ukraine "On Local Self-Government in Ukraine", at the same time the influence of modern political and economic researched. It is determined that in Ukraine there is no idea at the state level about the role of local self-government, on the one hand, it emphasizes the current and necessary role of community interests in the field, and on the other - the issue of state regulation remains open. All this has led to the emergence of modern research on local government as an innovative activity for modeling political processes on the ground.

Keywords: local self-government, local self-government reform, investment potential, public administration 